\title{
Cold Hardiness, Deacclimation Kinetics, and Bud Development among 12 Diverse Blueberry Genotypes under Field Conditions
}

\author{
Lisa J. Rowland ${ }^{1}$ and Elizabeth L. Ogden \\ U.S. Department of Agriculture, Agricultural Research Service, Henry A. Wallace Beltsville Agricultural \\ Research Center, Fruit Laboratory, Building 010A, BARC-West, Beltsville, MD 20705 \\ Mark K. Ehlenfeldt \\ U.S. Department of Agriculture, Agricultural Research Service, Blueberry and Cranberry Research \\ Center, 125A Lake Oswego Road, Chatsworth, NJ 08019
}

\author{
Bryan Vinyard \\ U.S. Department of Agriculture, Agricultural Research Service, Henry A. Wallace Beltsville Agricultural \\ Research Center, Biometrical Consulting Service, Building 005, BARC-West, Beltsville, MD 20705
}

\begin{abstract}
AdDITIONAL INDEX wORDS. dehardening, freezing tolerance, Vaccinium angustifolium, Vaccinium ashei, Vaccinium constablaei, Vaccinium corymbosum, Vaccinium darrowi, Vaccinium tennellum
\end{abstract}

\begin{abstract}
Deacclimation response is an important part of reproductive success in woody perennials because late winter or early spring thaws followed by hard freezes can cause severe injury to dehardened flower buds. There is a need to develop more spring-frost tolerant cultivars for the blueberry (Vaccinium L.) industry. The identification of later or slower deacclimating genotypes could be useful in breeding for more spring-frost tolerant cultivars. This study was undertaken to investigate cold hardiness and deacclimation kinetics under field conditions for 12 Vaccinium (section Cyanococcus A. Gray) genotypes (the cultivars Bluecrop, Duke, Legacy, Little Giant, Magnolia, Northcountry, Northsky, Ozarkblue, Pearl River, Tifblue, and Weymouth; and a population of $V$. constablaei Gray) with different germplasm compositions and expected mid-winter bud hardiness levels. Examination of bud cold hardiness (BCH) vs. weeks of deacclimation over a 7 -week period in 2 consecutive years (2002 and 2003$)$ revealed clear genotypic differences in cold hardiness and timing and rate of deacclimation. Among cultivars, 'Legacy' was the least cold hardy at initial evaluation, even less so than 'Tifblue'. Regarding deacclimation kinetics, the weekly intervals with the largest losses (i.e., high rates of deacclimation) also varied among genotypes. For 'Duke', the largest losses in BCH were detected at weeks 2 and 3, making it the earliest deacclimator. For 'Bluecrop', 'Ozarkblue', 'Weymouth', 'Tifblue', and 'Legacy', the greatest losses in BCH were observed at weeks 3 and 4. For 'Little Giant', 'Magnolia', 'Northcountry', 'Northsky', and 'Pearl River', losses in BCH were greatest at weeks 4 and 5, while for $V$. constablaei, losses were greatest at weeks 6 and 7, making it the latest deacclimator. Deacclimation kinetics were not correlated with mid-winter hardiness or chilling requirements in any fixed pattern. On the other hand, a strong positive correlation was found between $\mathrm{BCH}$ and stage of bud opening $(r=\mathbf{0 . 8 4})$. A comparison of timing of deacclimation with germplasm composition indicated that $V$. constablaei was particularly late to deacclimate. 'Little Giant', a 50:50 hybrid of $V$. constablaei and $V$. ashei Reade, was nearly as late to deacclimate as the $100 \% \mathrm{~V}$. constablaei selections. Thus, $V$. constablae $i$ may be useful in breeding programs to contribute genes for late deacclimation, which should translate into greater spring frost tolerance, in addition to genes for mid-winter hardiness.
\end{abstract}

There are over 150,000 acres of cultivated blueberries in North America at present (Ballington, 2001; Trinka, 1996), and the United States is the world's leading producer. In a survey of all the blueberry research and extension scientists in the United States, lack of winter hardiness and susceptibility to spring frosts have been identified as two of the most important problems of current cultivars (Moore, 1993). In the northern production regions of blueberry, winter damage is considered the major factor limiting yields (Hanson and Hancock, 1990; Moore, 1994). In nearly all blueberry growing areas in the United States, economic losses from early spring frosts can be very significant.

To ultimately develop more spring-frost resistant cultivars, we have begun studying the deacclimation process (loss of cold

Received for publication 16 Dec. 2004. Accepted for publication 9 Feb. 2005. ${ }^{1}$ To whom reprint request should be addressed; e-mail: rowlandj@ba.ars.usda. gov; phone: 301-504-6654; fax: 301-504-5062 hardiness with exposure to warm temperatures), as opposed to cold acclimation, in blueberry. Deacclimation response is an important part of reproductive success in woody perennials because late winter or early spring warm spells followed by hard freezes can cause severe injury to dehardened flower buds. Ideally, blueberry cultivars should deacclimate slowly or later during spring or unseasonable warm spells in winter without adversely delaying the time of fruiting. If differences in the timing and rate of deacclimation exist among blueberry genotypes, the identification of more slowly or later deacclimating genotypes could be useful in breeding for more spring-frost tolerant cultivars. Recently, we examined the rate of deacclimation among five blueberry cultivars under constant, warm temperatures (20 ${ }^{\circ} \mathrm{C}$ ). We found that cultivars with more of the southern species $V$. ashe $i$ in their backgrounds generally deacclimated earlier than the predominantly V. corymbosum L. cultivars (Arora et al., 2004). Constant temperatures, however, may not adequately reflect the deacclimation conditions encountered in the field, where con- 
tinuously varying temperatures may prevail. In this study, we examined deacclimation kinetics under field conditions, among 12 blueberry genotypes with different germplasm compositions and mid-winter cold hardiness levels. The relationship between flower bud opening during the deacclimation regime and the level of bud hardiness was also examined.

\section{Materials and Methods}

Plant material. Twelve blueberry genotypes were used for this study: cultivars Bluecrop (4X), Duke (4X), Legacy (4X), Little Giant (6X), Magnolia (4X), Northcountry (4X), Northsky (4X), Ozarkblue (4X), Pearl River (5X), Tifblue (6X), and Weymouth $(4 \mathrm{X})$; and a $V$. constablaei population $(6 \mathrm{X})$. The germplasm compositions of the genotypes are given in Table 1. Germplasm composition was determined from previously published sources (Clark et al., 1996; Ehlenfeldt, 1994; Hancock and Siefker, 1982). The $V$. constablaei population was a cross between two V. constablaei breeding selections, NC 86-40-2 and NC 86-28-3. The genotypes represented a wide range of bud hardiness levels based on either the genotypes' known mid-winter flower bud hardiness (e.g., 'Bluecrop', 'Legacy', 'Ozarkblue', 'Tifblue', and 'Weymouth') from previous studies (Arora et al., 1997, 2004; Muthalif and Rowland, 1994) or germplasm composition (i.e., the relative amount of cold hardy or cold sensitive germplasm in their ancestry). Shoots of 'Bluecrop', 'Duke', 'Legacy', 'Ozarkblue', and 'Weymouth' came from mature plants on a commercial farm in Hammonton, N.J. Shoots of 'Little Giant', 'Magnolia', 'Northcountry', 'Northsky', 'Pearl River', and V. constablaei came from mature plants in nearby ( $22 \mathrm{~km}$ away) experimental plantings at the P.E. Marucci Center for Blueberry and Cranberry Research and Extension (Rutgers Univ.) in Chatsworth, N.J. Shoots of mature 'Tifblue' plants came from a field plot at the Henry A. Wallace Agricultural Research Station at Beltsville, Md.

Determination OF FLOWER BUD COLD HARDiness. Detached shoots were assayed at weekly or biweekly intervals in 2002 (29 Jan. through 16 Apr.) and 2003 (4 Mar. through 15 Apr.) to determine bud cold hardiness $(\mathrm{BCH})$ and timing and rate of deacclimation during late winter and early spring. All plants for shoot collection were at least $4-5$ years old. Shoots were cut from groups of 20 or more plants of each cultivar except 'Magnolia', 'Northcountry', 'Northsky', and 'Pearl River', for which we had only two plants. For the V. constablaei population, shoots from six of the more vigorous and well-budded plants were sampled and bulked. We strove for as much uniformity as possible when sampling the shoots. Most samples were from terminal shoots taken from upper portions of the bush where they would have been above the snow-line, especially a concern on the half-highs. Because of the limited number of plants and/or shoots available for some genotypes ('Little Giant', 'Magnolia', 'Northcountry', 'Northsky', 'Pearl River', and V. constablaei), sampling was done biweekly, whereas for the other genotypes, sampling was done at weekly intervals. For the freeze-thaw protocol, 5- to 6-cm-long shoots with three to eight flower buds attached were used as described previously by Arora et al. (2004). Initial treatment temperatures chosen for fully cold acclimated buds covered a range from -10 to $-28{ }^{\circ} \mathrm{C}$ (the lowest temperature that the glycol freezing bath would consistently reach) at $2{ }^{\circ} \mathrm{C}$ increments, to represent $0 \%$ to $100 \%$ injury to blueberry buds for most genotypes (Arora et al., 1997). As the buds became more and more deacclimated, the treatment temperature ranges and the temperature increments between the samplings of frozen buds were adjusted to succes- sively higher (less negative) starting and ending temperatures (for temperature ranges) and, in some cases, to narrower sampling intervals (i.e., temperature increments). Controls included similarly handled shoots that were kept on ice with no exposure to the glycol freezing bath.

Shoots were removed from the freezing bath at respective treatment temperatures, thawed overnight at $4{ }^{\circ} \mathrm{C}$, and incubated at $20{ }^{\circ} \mathrm{C}$ for $24-\mathrm{h}$. Buds were then dissected and observed for injury (visual browning of the ovaries in individual flowers) (Arora et al., 2000; Flinn and Ashworth, 1994). Each bud was rated for percentage of injured ovaries and $\mathrm{BCH}$ was defined as the temperature causing $50 \%$ injury overall $\left(\mathrm{LT}_{50}\right)$.

STATISTICAL ANALYSIS OF BCH DATA AND DEACCLIMATION KINETICS. Bootstrap estimates (Manly, 1997) of $\mathrm{LT}_{50}$ values and their 95\% fiducial confidence intervals were calculated across weeks of deacclimation using Proc Probit (SAS, 1999) for each genotype $\times$ year combination. The nine observed data points (three proximal buds on each of the three shoots) for each temperature were resampled ( $n=9$ with replacement) 30 times. A sigmoidal (i.e., logistic) regression model was fit to percentage of injury (browning) vs. treatment temperature for each of the 30 sets of resampled data, and the 30 resulting values of $\mathrm{LT}_{50}$ and their lower and upper confidence limits were averaged to obtain bootstrap estimates at each week of deacclimation. The bootstrapped $\mathrm{LT}_{50}$ estimates obtained at weeks 4-10 of 2002 (19 Feb. 2002-9 Apr. 2002) corresponded most closely to estimates obtained at weeks 1-7 of 2003 (4 Mar. 2003-15 Apr. 2003). Thus, these estimates were averaged and the averages used to evaluate the deacclimation kinetics for each genotype by fitting a log-linear or asymmetric sigmoidal (Gompertz) model, depending on the genotype, to model the relationship between $\mathrm{LT}_{50}$ and week of deacclimation. The $\mathrm{LT}_{50}$ estimates from the models at each week of deacclimation and the differences in $\mathrm{LT}_{50}$ values between subsequent weeks were compared among genotypes by using analysis of covariance (Milliken and Johnson, 2002).

BUD DEVELOPMENT AND ITS RELATIONSHIP TO BCH. At each sampling for $\mathrm{BCH}$, three to five shoots with five to eight floral buds were evaluated for the stage of bud opening. Stages of flower-bud opening were ranked on the scale of 1-7 as described by Spiers (1978), with 1 representing the stage with no visible swelling and 7 representing the stage after which corollas had completely expanded and dropped. Percentage of buds at stages 1-7 was recorded for each weekly sampling and, from this, the average bud score for each week of deacclimation was calculated. Flower bud development scores from weeks 4-10 of year 2002 were then averaged with scores from weeks $1-7$ of year 2003. The correlation between bud opening (average bud score) and $\mathrm{BCH}$ values was determined using SAS Proc CORR (SAS Institute, 1999).

\section{Results and Discussion}

COMPARISON OF COLD ACCLIMATED BCH OF BLUEBERRY GENOTYPES. The genotypes selected for this study represented a range of different germplasm compositions (Table 1) and expected BCH levels. In our earlier deacclimation study using controlled constant, warm temperatures, we determined the $\mathrm{BCH}$ of fully cold acclimated plants of the cultivars Bluecrop, Legacy, Ozarkblue, Tifblue, and Weymouth. Those results indicated that 'Bluecrop' and 'Weymouth' were the hardiest, followed by 'Ozarkblue', 'Tifblue', and 'Legacy' (Arora et al., 2004). Vaccinium constablaei is a highbush-like hexaploid species that, although native to the 
Table 1. Germplasm composition of Vaccinium genotypes evaluated for mid-winter bud cold hardiness and timing and rate of deacclimation. Genotypes are ranked in the approximate order of winter hardiness as determined in this study, evaluated by mid-winter cold hardiness, timing and rate of deacclimation, and bud opening. This order is maintained on subsequent tables.

\begin{tabular}{|c|c|c|c|c|c|c|}
\hline \multirow[b]{3}{*}{ Genotype } & \multicolumn{6}{|c|}{ Germplasm $(\%)^{z}$} \\
\hline & \multicolumn{3}{|c|}{ Cold hardy } & \multicolumn{3}{|c|}{ Cold sensitive } \\
\hline & V. cor. $^{\mathrm{y}}$ & V. ang. & V.con. & V. dar. & V.ash. & V.ten. \\
\hline Legacy & 73 & 2 & --- & 25 & --- & --- \\
\hline Tifblue & --- & --- & --- & --- & 100 & --- \\
\hline Pearl River ${ }^{x}$ & 69 & 1 & --- & --- & 30 & --- \\
\hline Magnolia & 71 & 6 & --- & 12 & 8 & 3 \\
\hline Bluecrop & 94 & 6 & --- & --- & --- & --- \\
\hline Ozarkbluew & 78 & 3 & --- & 9 & 9 & --- \\
\hline Weymouth & 87.5 & 12.5 & --- & --- & --- & --- \\
\hline Duke & 96 & 4 & --- & --- & --- & --- \\
\hline Northcountry & 73 & 27 & --- & --- & --- & --- \\
\hline Northsky & 73 & 27 & --- & --- & --- & --- \\
\hline Little Giant & --- & --- & 50 & --- & 50 & --- \\
\hline V. constablaei & --- & --- & 100 & --- & --- & --- \\
\hline
\end{tabular}

${ }^{\mathrm{z}}$ According to Clark et al., 1996; Ehlenfeldt, 1994; Hancock and Siefker, 1982.

$\mathrm{y} V$. cor.$=V$. corymbosum,$V$. ang. $=V$. angustifolium,$V$. dar.$=V$. darrowi, $V$. ash.$=V$. ashei,$V$. con.$=V$. constablaei, $V$. ten.$=V$. tennellum

xThe pedigree of one parent of 'Pearl River' is debatable. If 'Beckyblue' is taken to be $100 \% \mathrm{~V}$. ashei, 'Pearl River' would then be $39 \% \mathrm{~V}$. corymbosum, $1 \% \mathrm{~V}$. angustifolium, and $60 \% \mathrm{~V}$. ashei (see comments by Sherman and Sharpe, 1978).

wThe pedigree calculations of 'Ozarkblue' are based upon the assumption that an intermediate ancestor from a cross of $V$. darrowi $(2 \mathrm{x}) \times V$. ashei (6x) was $25 \%$ V. darrowi and $75 \%$ V.ashei (see Clark et al., 1996). Totals for 'Ozarkblue' add up to $<100 \%$ due to rounding of values.

southern United States, is found at high elevations in northern Georgia, western North Carolina, and eastern Tennessee. Vaccinium corymbosum and $V$. angustifolium Ait. are northern tetraploid highbush and lowbush species, respectively. The diploid lowbush species, V. darrowi Camp and V. tennellum Ait., and the hexaploid species $V$. ashei (rabbiteye) are found in the southern United States. Based on their native habitat, V. constablaei and $V$. angustifolium are expected to be the most cold hardy, followed by V. corymbosum, V. darrowi, V. tennellum, and V. ashei.

To first compare the $\mathrm{BCH}$ of blueberry genotypes when they were fully cold acclimated and had not begun to deaccclimate, we began sampling shoots in late Jan. 2002 and early Mar. 2003. Sampling continued through about mid-April for both years. Sampling was begun earlier in 2002 because Winter 2001-02 was relatively mild, with monthly averages of $12.3,8.6,5.0,2.7$, and $3.1^{\circ} \mathrm{C}$, for the months of October through February, respectively, for the Chatsworth, N.J., site. The last week of November saw a weekly average of $14.0^{\circ} \mathrm{C}$ and the lowest weekly-average temperature of the winter was $-3.5^{\circ} \mathrm{C}$ in the first week of January. Three weeks before the start of evaluations, the weekly average was $7.8^{\circ} \mathrm{C}$. By comparison, Winter 2002-03 was relatively colder. Monthly averages were $12.9,6.5,1.5,-2.4$, and $-1.6^{\circ} \mathrm{C}$, for the months of October through February. The first week of December saw a weekly average of $-2.1{ }^{\circ} \mathrm{C}$, and the second-to-last week of January saw the lowest weekly average of the winter at $-6.8^{\circ} \mathrm{C}$. Three weeks before the start of evaluations, the weekly average was $-4.8^{\circ} \mathrm{C}$. Weekly and monthly temperature averages for the Beltsville, Md., site were within $0.1-2.1{ }^{\circ} \mathrm{C}$ of those reported for Chatsworth, N.J., except for 3 weeks before the start of evalu- ations in 2002-03, where the weekly average was $-1.4{ }^{\circ} \mathrm{C}$ for Beltsville, $3.4^{\circ} \mathrm{C}$ colder than that for Chatsworth.

Although Winter 2002 was milder than that of 2003 and sampling was begun earlier in 2002, a detectable decrease (more positive $\left.\mathrm{LT}_{50} \mathrm{~s}\right)$ in $\mathrm{BCH}$ in 2002 did not occur until sometime between week 4(19Feb. 2002) and week 5 (26 Feb. 2002). Therefore, BCH data for weeks 1-3 of 2002 are not shown. A decrease in BCH in 2003 occurred sometime between week 1 (4 Mar. 2003) and week 2 (11 Mar. 2003). A comparison of BCH in 2002 and 2003 for the 7-week period, corresponding to weeks 4-10 in 2002 and weeks $1-7$ in 2003, revealed remarkably similar levels (Table 2). Only 8 of the 48 comparisons that could be made found a significant difference in $\mathrm{BCH}$ levels between the 2 years. Consequently, $\mathrm{BCH}$ data from weeks 4-10 of year 2002 were averaged with

Table 2. Flower bud cold hardiness over a 7-week period [corresponding to weeks 4-10 in 2002 study (19 Feb.-9 Apr.) and weeks 1-7 in 2003 study (4 Mar.-15 Apr.)] for field-grown plants of 12 blueberry genotypes.

\begin{tabular}{|c|c|c|c|c|c|c|c|}
\hline \multirow[b]{2}{*}{ Genotype } & \multicolumn{7}{|c|}{ Bud cold hardiness $\left({ }^{\circ} \mathrm{C}\right)$} \\
\hline & Week $4 / 1^{z}$ & $5 / 2$ & $6 / 3$ & $7 / 4$ & $8 / 5$ & $9 / 6$ & $10 / 7$ \\
\hline \multicolumn{8}{|l|}{ Bluecrop } \\
\hline 2002 & -24.9 & -22.6 & -20.0 & -13.9 & -13.3 & -9.8 & -10.5 \\
\hline 2003 & -25.9 & -23.4 & -19.4 & -14.3 & -11.5 & -10.7 & -9.0 \\
\hline \multicolumn{8}{|l|}{ Duke } \\
\hline 2002 & -24.3 & -22.0 & -21.0 & -13.9 & -14.4 & -10.3 & -11.1 \\
\hline 2003 & -26.9 & -23.8 & -20.4 & -14.5 & -12.1 & -8.2 & $-7.8^{*}, y$ \\
\hline \multicolumn{8}{|l|}{ Legacy } \\
\hline 2002 & -15.0 & -12.5 & -12.8 & -6.3 & -11.5 & -10.4 & -9.9 \\
\hline 2003 & -17.1 & $-17.9^{*}$ & -14.7 & $-12.2^{*}$ & -10.4 & -10.3 & -7.8 \\
\hline \multicolumn{8}{|l|}{ Little Giant } \\
\hline 2002 & $\leq 28$ & $\mathrm{ND}^{\mathrm{x}}$ & -27.7 & ND & -19.5 & ND & -17.9 \\
\hline 2003 & $\leq 28$ & $\leq 28$ & ND & -20.8 & ND & -18.5 & $-13.7^{*}$ \\
\hline \multicolumn{8}{|l|}{ Magnolia } \\
\hline 2002 & ND & -23.4 & ND & -18.3 & ND & -14.9 & ND \\
\hline 2003 & ITD $^{w}$ & ND & -21.3 & -18.9 & ND & -16.5 & -9.9 \\
\hline \multicolumn{8}{|c|}{ Northcountry } \\
\hline 2002 & ND & -27.4 & ND & -18.9 & ND & -14.0 & $\mathrm{ND}$ \\
\hline 2003 & -28.0 & ND & -24.3 & ND & -14.2 & -15.8 & $\mathrm{ND}$ \\
\hline \multicolumn{8}{|l|}{ Northsky } \\
\hline 2002 & ND & -28.4 & ND & -22.9 & ND & -15.1 & ND \\
\hline 2003 & -28.4 & ND & -25.5 & ND & -15.8 & -16.5 & -14.1 \\
\hline \multicolumn{8}{|l|}{ Ozarkblue } \\
\hline 2002 & -25.1 & -23.0 & -22.0 & -12.8 & -13.2 & -11.3 & -11.2 \\
\hline 2003 & -25.8 & -23.5 & $-17.4^{*}$ & -12.5 & -10.3 & -10.6 & $-8.7^{*}$ \\
\hline \multicolumn{8}{|l|}{ Pearl River } \\
\hline 2002 & -21.4 & ND & -20.5 & ND & -14.2 & ND & ITD \\
\hline 2003 & ITD & ITD & ND & -16.6 & ND & -13.6 & -13.0 \\
\hline \multicolumn{8}{|l|}{ Tifblue } \\
\hline 2002 & -19.1 & -16.6 & -15.2 & -11.5 & -11.4 & -11.0 & -8.7 \\
\hline 2003 & -20.9 & $-19.2^{*}$ & -14.9 & -12.2 & -10.6 & -10.3 & -9.2 \\
\hline \multicolumn{8}{|c|}{ V. constablaei } \\
\hline 2002 & ND & $\leq 28.0$ & ND & $\leq 28.0$ & ND & -23.0 & ND \\
\hline 2003 & ND & ND & -28.0 & ND & -24.0 & -23.0 & -19.0 \\
\hline \multicolumn{8}{|l|}{ Weymouth } \\
\hline 2002 & -24.4 & -20.0 & -18.7 & -12.2 & -13.0 & -8.9 & -9.9 \\
\hline 2003 & -27.2 & $-25.7^{*}$ & -18.6 & -13.5 & -10.9 & -10.4 & -12.4 \\
\hline
\end{tabular}

${ }^{2}$ Week in 2002/comparable week in 2003. Collection dates for 2002 were: week $4=19$ Feb., week $5=26$ Feb., week $6=7$ Mar., week $7=19$ Mar., week $8=26$ Mar., week $9=2$ Apr., week $10=9$ Apr. Collection dates for 2003 were: week $1=4$ Mar., week $2=11$ Mar., week $3=18$ Mar., week $4=25$ Mar., week $5=1$ Apr., week $6=8$ Apr., week $7=15$ Apr.

yAsterisk indicates that the bud cold hardiness level at this time point was significantly different from the year before as determined by $95 \%$ fiducial confidence limits.

$\times \mathrm{ND}=$ not done

wITD = impossible to determine because of too much damage on control shoots. 
data from weeks 1-7 of year 2003 and are hereafter referred to as weeks $1-7$ of the combined-year study (Table 3 ).

Data from blueberry genotypes from week 1 [week 2 for 'Magnolia' and $V$. constablaei in the combined-year study, or weeks 1 and 3 in year 2002 study (data not shown)], when they were fully cold acclimated and had not begun to deacclimate, indicated that there were significant differences in the initial BCH among the cultivars. Vaccinium constablaei, 'Little Giant', 'Northsky', 'Northcountry', 'Weymouth', 'Duke', 'Bluecrop', and 'Ozarkblue' were the hardiest, followed by 'Magnolia', 'Pearl River', 'Tifblue', and 'Legacy' (Table 3). 'Legacy' was notable as being significantly less cold hardy than all the other cultivars. For the most cold-hardy genotypes, V. constablaei and 'Little Giant' (50\% V. constablaei), $50 \%$ injury was not achieved at $-28{ }^{\circ} \mathrm{C}$, the lowest temperature that the glycol freezing bath would reach. Flower buds of the fully cold acclimated V. constablaei and 'Little Giant' plants sustained $30 \%$ to $40 \%$ damage at $-28{ }^{\circ} \mathrm{C}$, suggesting that their $\mathrm{LT}_{50} \mathrm{~s}$ were probably in the $-30{ }^{\circ} \mathrm{C}$ range. Their $\mathrm{LT}_{50} \mathrm{~s}$ are listed as being less than $-28.0^{\circ} \mathrm{C}$ in Table 3 ; however, for the sake of statistical analysis and a conservative comparison to the other genotypes, their $\mathrm{LT}_{50} \mathrm{~s}$ were treated as being $-28.0^{\circ} \mathrm{C}$. The cold acclimated $\mathrm{BCH}$ results are in accordance with our earlier reports on the BCH levels of 'Bluecrop', 'Legacy', 'Ozarkblue', 'Tifblue', and 'Weymouth' evaluated using similar protocols (Arora et al., 1997, 2004; Muthalif and Rowland, 1994). For the most part, these results are also in accordance with expectations based on parentage, in that the V. constablaei genotypes and the $V$. corymbosum $\mathrm{x}$ V. angustifolium half-high cultivars Northcountry and Northsky would be expected to be the most cold hardy, followed by the predominantly $V$. corymbosum highbush cultivars Bluecrop, Duke, and Weymouth. The genotypes with southern species in their backgrounds, such as 'Legacy', 'Magnolia', 'Ozarkblue', 'Pearl River', and 'Tifblue', would be expected to be less cold hardy. The only exception to this was 'Ozarkblue', which was just as cold hardy as 'Bluecrop', 'Duke', and 'Weymouth', despite having $18 \%$ cold sensitive germplasm in its background (9\% V. darrowi and 9\% V. ashei). This suggests that 'Ozarkblue' may have broad environmental adaptation. This expectation is

Table 3. Combined 2002 and 2003 data for flower bud cold hardiness of field-grown plants of 12 blueberry genotypes over a 7-week period.

\begin{tabular}{lccccccc}
\hline & \multicolumn{7}{c}{ Avg bud cold hardiness $\left({ }^{\circ} \mathrm{C}\right)$} \\
\cline { 2 - 8 } Genotype & Week 1 & Week 2 & Week 3 & Week 4 & Week 5 & Week 6 & Week 7 \\
\hline Legacy & $-16.0 \mathrm{c}$ & $-15.2 \mathrm{c}$ & $-13.8 \mathrm{~d}$ & $-9.2 \mathrm{~g}$ & $-10.9 \mathrm{e}$ & $-10.3 \mathrm{~cd}$ & $-8.8 \mathrm{~d}$ \\
Tifblue & $-20.0 \mathrm{~b}$ & $-17.9 \mathrm{c}$ & $-15.1 \mathrm{~d}$ & $-11.8 \mathrm{f}$ & $-11.0 \mathrm{e}$ & $-10.6 \mathrm{~cd}$ & $-8.9 \mathrm{~d}$ \\
Pearl River & $-21.4 \mathrm{ab}$ & --- & $-20.5 \mathrm{bc}$ & $-16.6 \mathrm{~b}-\mathrm{f}$ & $-14.2 \mathrm{bc}$ & $-13.6 \mathrm{bc}$ & $-13.0 \mathrm{bc}$ \\
Magnolia & ITD & $-23.4 \mathrm{ab}$ & $-21.3 \mathrm{a}-\mathrm{c}$ & $-18.6 \mathrm{~b}-\mathrm{d}$ & --- & $-15.7 \mathrm{~b}$ & $-9.9 \mathrm{~d}$ \\
Bluecrop & $-25.4 \mathrm{a}^{\mathrm{y}}$ & $-23.0 \mathrm{~b}$ & $-19.7 \mathrm{c}$ & $-14.1 \mathrm{~d}-\mathrm{f}$ & $-12.4 \mathrm{de}$ & $-10.2 \mathrm{~d}$ & $-9.8 \mathrm{~d}$ \\
Ozarkblue & $-25.4 \mathrm{a}$ & $-23.3 \mathrm{~b}$ & $-19.7 \mathrm{c}$ & $-12.6 \mathrm{ef}$ & $-11.8 \mathrm{de}$ & $-10.9 \mathrm{~cd}$ & $-9.9 \mathrm{~d}$ \\
Weymouth & $-25.8 \mathrm{a}$ & $-22.9 \mathrm{~b}$ & $-18.6 \mathrm{c}$ & $-12.9 \mathrm{ef}$ & $-11.9 \mathrm{de}$ & $-9.7 \mathrm{~d}$ & $-11.1 \mathrm{~cd}$ \\
Duke & $-25.6 \mathrm{a}$ & $-22.9 \mathrm{~b}$ & $-20.7 \mathrm{bc}$ & $-14.2 \mathrm{c}-\mathrm{e}$ & $-13.3 \mathrm{c}-\mathrm{e}$ & $-9.2 \mathrm{~d}$ & $-9.4 \mathrm{~d}$ \\
Northcountry & $-28.0 \mathrm{a}$ & $-27.4 \mathrm{ab}$ & $-24.3 \mathrm{ab}$ & $-18.9 \mathrm{bc}$ & $-14.2 \mathrm{~b}-\mathrm{d}$ & $-14.9 \mathrm{~b}$ & --- \\
Northsky & $-28.4 \mathrm{a}$ & $-28.4 \mathrm{a}$ & $-25.5 \mathrm{a}$ & $-22.9 \mathrm{ab}$ & $-15.8 \mathrm{bc}$ & $-15.8 \mathrm{~b}$ & $-14.1 \mathrm{a}-\mathrm{c}$ \\
Little Giant & $\leq 28.0 \mathrm{a}$ & $\leq 28.0 \mathrm{a}$ & $-27.7 \mathrm{a}$ & $-20.8 \mathrm{~b}$ & $-19.5 \mathrm{ab}$ & $-18.5 \mathrm{~b}$ & $-15.8 \mathrm{ab}$ \\
V. constablaei & --- & $\leq 28.0 \mathrm{a}$ & $-28.0 \mathrm{a}$ & $\leq 28.0 \mathrm{a}$ & $-24.0 \mathrm{a}$ & $-23.0 \mathrm{a}$ & $-19.0 \mathrm{a}$ \\
\hline
\end{tabular}

${ }^{2}$ Bud cold hardiness data from weeks $4-10$ of year 2002 were averaged with data from weeks 1-7 of year 2003 and are herein referred to as weeks 1-7. Collection dates for 2002 were: week $4=19$ Feb., week $5=26 \mathrm{Feb}$., week $6=7$ Mar., week $7=19$ Mar., week $8=26$ Mar., week $9=2$ Apr., week 10 = 9 Apr. Collection dates for 2003 were: week $1=4$ Mar., week $2=11$ Mar., week $3=18$ Mar., week $4=25$ Mar., week $5=1$ Apr., week $6=8$ Apr., week $7=15$ Apr.

y Mean separation among genotypes within columns determined by $95 \%$ fiducial confidence limits. ${ }^{x}$ ITD $=$ impossible to determine because of too much damage on control shoots. also supported by the empirical observation by the authors that, under field conditions, its $50 \%$ flowering date across 5 years has the latest of more than 100 highbush and southern highbush . constablaei germplasm in promotexcept pure $V$. constablaei. This knowledge is valuable, and is currently being utilized in the development of cold-hardy $V$. ashei Confeldt and Rowland, in press).

COMPARISON OF DEACCLIMATION KINETICS OF BLUEBERRY GENOTYPES. The decrease in $\mathrm{BCH}$ at each weekly interval across notypes was quite varied; some genotypes lost more $\mathrm{BCH}$ early phases, some in the middle, and some in the fina Aeeks, a decrease in BCH was detectable in 7 of 12 genotypes by week 2 (Table 3 ). By week 3 , five cultivars 列, (statistical comparison nonsignificant decrease in their cold acclimated $\mathrm{BCH}$ of $9 \%$ 14\%; 'Pearl River' had lost 4\%; and the remaining genotypes no detectable change. By week 4, each of the genotypes (he study (week 7), each genotype stablaei which had lost only $32 \%$ BCH. At week 7, V. constablaei still had the lowest $\mathrm{LT}_{50}$ (most cold hardy) of $-19.0^{\circ} \mathrm{C}$, followed by 'Little Giant' $\left(-15.8^{\circ} \mathrm{C}\right)$, 'Northsky' $\left(-14.1^{\circ} \mathrm{C}\right)$, 'Pearl River' $\left(-13.0^{\circ} \mathrm{C}\right)$, and 'Weymouth' $\left(-11.1^{\circ} \mathrm{C}\right)(\mathrm{BCH}$ of 'Northcountry' as not determined at week 7). All of the other genotypes had $\mathrm{LT}_{50} \mathrm{~S}$ in the range of -8.8 to $-9.9^{\circ} \mathrm{C}$. It is notable that although 'Magnolia' had deacclimated to a level of $-9.9^{\circ} \mathrm{C}$ by week 7 , it along with 'Pearl River' was more cold hardy than 'Bluecrop', 'Ozarkblue', 'Weymouth', and 'Duke' during most weeks of evaluation.

Deacclimation models (log-linear for 'Duke' and Gompertz for all other genotypes) fitted to the observed $\mathrm{BCH}$ values for the combined-year study are shown in Fig. 1. Changes in $\mathrm{BCH}$ for each weekly interval during the 7-week period (= rates of deacclimation for each 1-week time interval) predicted from the deacclimation models are shown in Table 4. The largest losses in $\mathrm{BCH}$, thus the fastest rates of deacclimation, occurred at different weekly intervals for the various genotypes. For the sake of discussion, in Table 4, the two fastest weekly periods of deacclimation are highlighted. For 'Duke', the largest losses in $\mathrm{BCH}$ were detected across weeks 2 and 3, making it the earliest deacclimator. For 'Bluecrop', 'Ozarkblue', and 'Weymouth' (all of which 
A.

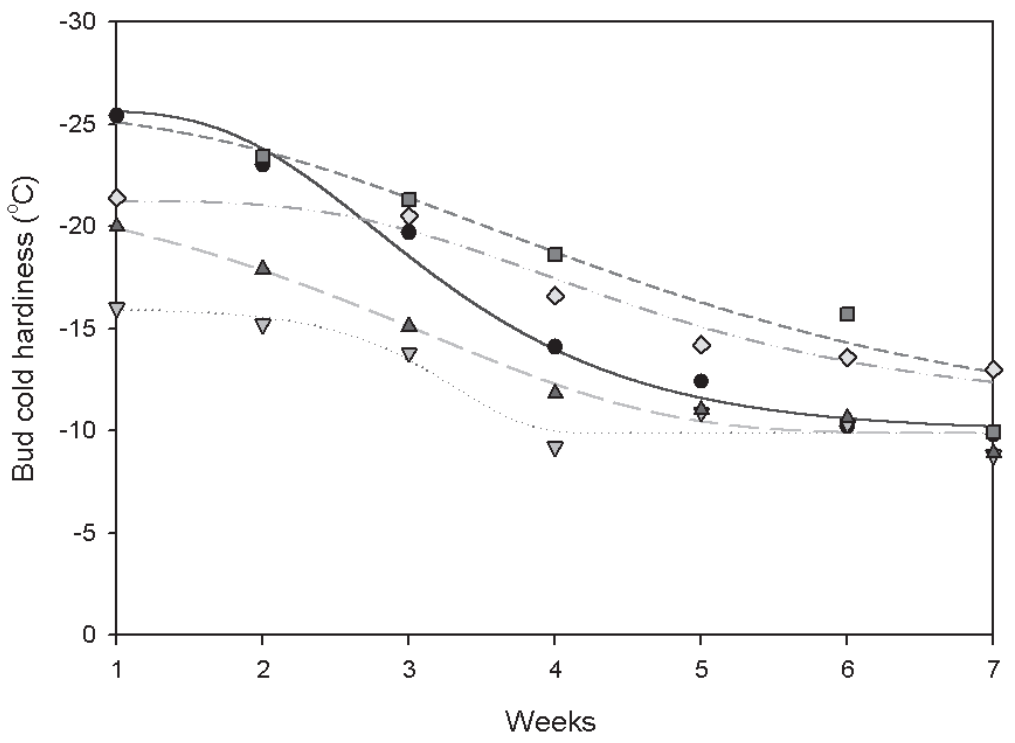

B.

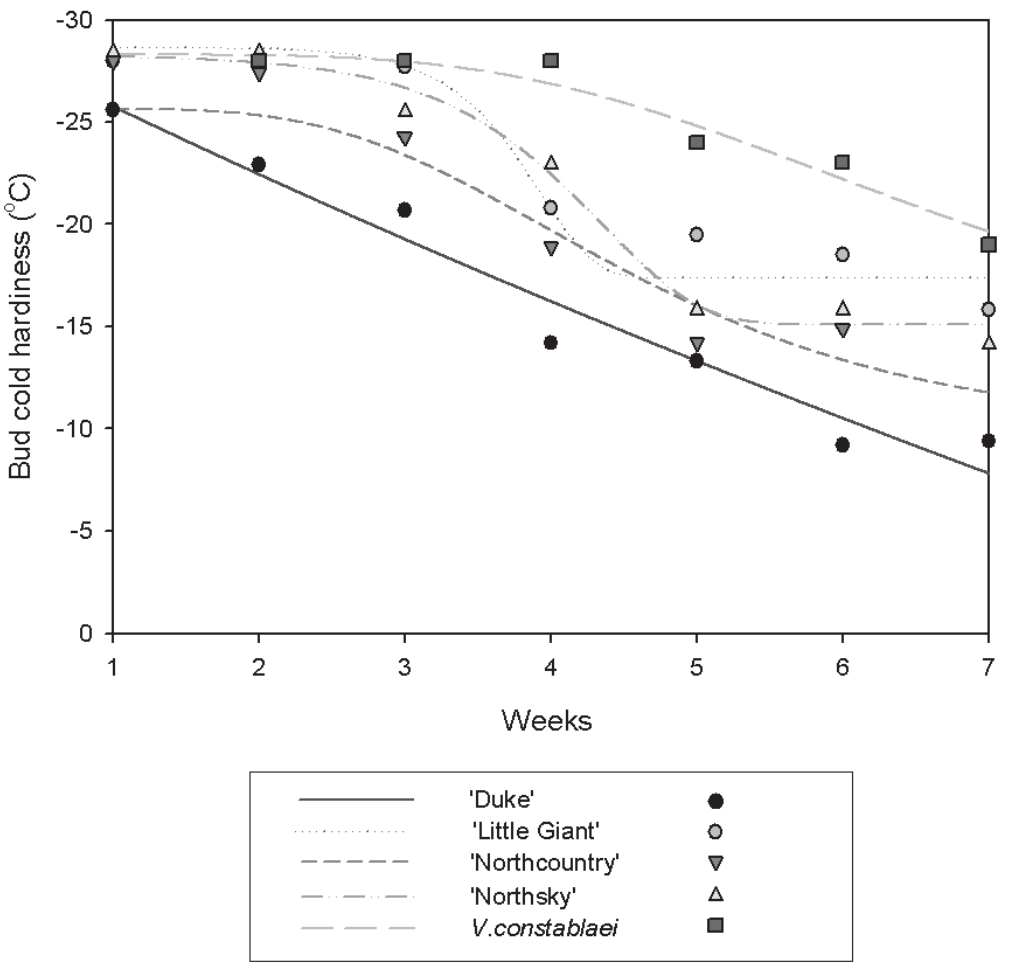

had deacclimation kinetics described by the same model), as well as 'Legacy' and 'Tifblue', the greatest losses in BCH were observed across weeks 3 and 4. Of these, 'Bluecrop', 'Ozarkblue', and 'Weymouth' had the largest losses of $\approx 10^{\circ} \mathrm{C}$, making them the fastest deacclimators over this time period. For 'Little Giant', 'Magnolia', 'Northcountry', 'Northsky', and 'Pearl River', losses in $\mathrm{BCH}$ were greatest across weeks 4 and 5. Of these, 'Little Giant' and 'Northsky' had the largest losses, also of $\approx 10^{\circ} \mathrm{C}$, over this time period. For $V$. constablaei, losses were greatest across weeks 6 and 7, making it the latest deacclimator.

From this study, genotypic differences in deacclimation response were clearly evident. In our previous deacclimation study using controlled constant, warm temperatures, differences were evident that suggested that the southern species, V.ashei, may contribute genes determining early, fast deacclimation, in addition to its expected contribution to cold sensitivity (Arora et al., 2004). In that study, 'Tifblue' (100\% V. ashei) was the earliest deacclimator, 'Ozarkblue' (9\% V. ashei) was intermediate, 'Weymouth' (0\% V. ashei) and 'Legacy' (0\% V. ashei) were late to intermediate, and 'Bluecrop' (0\% V. ashei) was the latest deacclimator. In the present field study of 12 genotypes, correlation of deacclimation response with cold hardy or cold sensitive germplasm composition was not as obvious, except for the genotypes with $V$. constablaei in their backgrounds (the $100 \%$ V. constablaei population and the $50 \% \mathrm{~V}$. constablaei cultivar Little Giant), which were two of the latest deacclimators. The cultivar

Fig. 1. Deacclimation of field-grown plants of 12 blueberry genotypes over a 7-week period (corresponding to weeks 4-10 in 2002 study and weeks 1-7 in 2003 study). Part A shows genotypes 'Bluecrop', 'Ozarkblue', 'Weymouth', 'Legacy', 'Magnolia', 'Pearl River', and 'Tifblue'. Part B shows genotypes 'Duke', 'Little Giant', 'Northcountry', 'Northsky', and Vaccinium constablaei. Curves show the bud cold hardiness $(\mathrm{BCH})$ values predicted from loglinear (for 'Duke') or Gompertz (for all other genotypes) models. Points represent actual observed values averaged over the 2 years. Log-linear models, which describe $\mathrm{BCH}$ values $(y)$ as a function of weeks of deacclimation $(x)$, are of the general form: $\mathrm{BCH}=\mathrm{a}$ $+\mathrm{b} x \log _{\mathrm{e}}($ weeks $+\mathrm{c})$. Gompertz models, which likewise describe $\mathrm{BCH}$ values $(y)$ as a function of weeks of deacclimation $(x)$, are of the general form: $\mathrm{BCH}=\mathrm{d}+\mathrm{ax} \exp [-\exp (\mathrm{b}-\mathrm{c} \mathrm{x}$ weeks $)]$. The specific equations, with parameter estimates shown, are:

Log-linear

'Duke': $\mathrm{BCH}=-242.47+71.24 \times \log _{\mathrm{e}}($ weeks +19.9$)$

Gompertz

'Bluecrop'/'Ozarkblue'/'Weymouth': BCH $=-25.66+15.71 \mathrm{x}$ $\exp [-\exp (2.72-0.99 \mathrm{x}$ weeks $)]$

'Legacy': $\mathrm{BCH}=-9.86+-6.11 \times \exp [-\exp (-6.55--1.98 \times$ weeks)]

'Little Giant': $\mathrm{BCH}=-17.39+-11.28 \mathrm{x} \exp [-\exp (-10.39--2.64$ $\mathrm{x}$ weeks)]

'Magnolia': $\mathrm{BCH}=-25.66+15.71 \mathrm{x} \exp [-\exp (1.65-0.46 \mathrm{x}$ weeks)]

'Northcountry': $\mathrm{BCH}=-25.66+15.71 \mathrm{x} \exp [-\exp (2.72-0.69 \mathrm{x}$ weeks)]

'Northsky': $\mathrm{BCH}=-15.1+-13.17 \mathrm{x} \exp [-\exp (-6.55--1.5 \mathrm{x}$ weeks)]

'Pearl River': $\mathrm{BCH}=-21.24+10.04 \times \exp [-\exp (2.72-0.69 \mathrm{x}$ weeks)]

'Tifblue': $\mathrm{BCH}=-9.86+-13.17 \mathrm{x} \exp [-\exp (-1.90--0.61 \mathrm{x}$ weeks)]

V. constablaei $: \mathrm{BCH}=-28.3+15.71 \times \exp [-\exp (2.72-0.46 \times$ weeks)] 
Table 4. Weekly changes in bud cold hardiness $(\mathrm{BCH})$ from deacclimation models generated for the 12 blueberry genotypes. The two highest weekly changes are set in boldface and connected with lines.

\begin{tabular}{lccccccc}
\hline & \multicolumn{5}{c}{ Weekly loss in BCH $\left({ }^{\circ} \mathrm{C}\right)\left[=\right.$ rate of deacclimation $\left({ }^{\circ} \mathrm{C} /\right.$ week $\left.)\right]$} \\
\cline { 2 - 7 } Genotype & Week 1 ${ }^{\mathrm{z}}$ & & & & & \\
\hline Legacy & -15.9 & $0.4 \mathrm{a}^{\mathrm{x}}$ & $\mathbf{2 . 1} \mathrm{bc}-\mathbf{3 . 5} \mathrm{b}-\mathrm{d}$ & $0.1 \mathrm{a}$ & $0 \mathrm{a}$ & $0 \mathrm{a}$ \\
Tifblue & -19.9 & $2.1 \mathrm{~b}$ & $\mathbf{2 . 7} \mathrm{bc}-\mathbf{2 . 8} \mathrm{bc}$ & $1.8 \mathrm{~b}$ & $0.5 \mathrm{ab}$ & $0 \mathrm{a}$ \\
Pearl River & -21.2 & $0.2 \mathrm{a}$ & $1.2 \mathrm{ab}$ & $\mathbf{2 . 4} \mathrm{b}-\mathbf{2 . 4} \mathrm{bc}$ & $1.7 \mathrm{bc}$ & $1.0 \mathrm{c}$ \\
Magnolia & -25.1 & $1.4 \mathrm{~b}$ & $2.3 \mathrm{bc}$ & $\mathbf{2 . 7} \mathrm{b}-\mathbf{2 . 5} \mathrm{bc}$ & $2.0 \mathrm{c}$ & $1.4 \mathrm{~cd}$ \\
Bc/Oz/Wey & -25.6 & $1.8 \mathrm{~b}$ & $\mathbf{5 . 2} \mathrm{d}-\mathbf{4 . 6} \mathrm{d}$ & $2.4 \mathrm{bc}$ & $1.0 \mathrm{~b}$ & $0.4 \mathrm{~b}$ \\
Duke & -25.8 & $\mathbf{3 . 3} \mathrm{c}-\mathbf{3 . 2} \mathrm{c}$ & $3.0 \mathrm{bc}$ & $2.9 \mathrm{c}$ & $2.8 \mathrm{~d}$ & $2.7 \mathrm{e}$ \\
Northcountry & -25.7 & $0.3 \mathrm{a}$ & $1.9 \mathrm{~b}$ & $\mathbf{3 . 7} \mathrm{cd}-\mathbf{3 . 7} \mathrm{d}$ & $2.6 \mathrm{~d}$ & $1.6 \mathrm{~d}$ \\
Northsky & -28.2 & $0.3 \mathrm{a}$ & $1.2 \mathrm{ab}$ & $\mathbf{4 . 2} \mathrm{cd}-\mathbf{6 . 4} \mathrm{d}$ & $1.0 \mathrm{a}-\mathrm{d}$ & $0 \mathrm{a}$ \\
Little Giant & -28.7 & $0.1 \mathrm{a}$ & $0.9 \mathrm{ab}$ & $\mathbf{7 . 0} \mathrm{d}-\mathbf{3 . 4} \mathrm{cd}$ & $0 \mathrm{a}$ & $0 \mathrm{a}$ \\
V. constablaei & -28.3 & $0 \mathrm{a}$ & $0.3 \mathrm{a}$ & $1.1 \mathrm{a}$ & $2.1 \mathrm{~b}$ & $\mathbf{2 . 6} \mathrm{d}$ & $\mathbf{2 . 6} \mathrm{e}$ \\
\hline
\end{tabular}

${ }^{2}$ Bud cold hardiness data from weeks 4-10 of year 2002 were averaged with data from weeks 1-7 of year 2003 to generate deacclimation models and are herein referred to as weeks 1-7. Collection dates for 2002 were: week $4=19$ Feb., week $5=26$ Feb., week $6=7$ Mar., week $7=19$ Mar., week $8=26$ Mar., week $9=2$ Apr., week $10=9$ Apr. Collection dates for 2003 were: week $1=4$ Mar., week $2=11$ Mar., week $3=18$ Mar., week $4=25$ Mar., week $5=1$ Apr., week $6=8$ Apr., week 7 $=15$ Apr.

yCA $=$ cold acclimated

xMean separation among genotypes within columns determined by analysis of covariance.

RELATIONSHIP OF BUD DEVELOPMENT AND DEACCLIMATION. To determine if the stage of bud opening could be used as an indicator of the level of $\mathrm{BCH}$, we examined bud opening in the progressively deacclimating flower buds of the 12 blueberry genotypes in 2002 and 2003. Like BCH data, bud opening data from weeks 4-10 of year 2002 were averaged with data from weeks $1-7$ of year 2003 (Table 5). At week 1 of the combined-year study, flower buds of all genotypes were fairly tightly closed with little or no visible swelling (average bud stage of 1.0-1.5). They became progressively more developed during the deacclimation regime, reaching stages of 2.3-4.0 by week 7 for all genotypes except V. constablaei and 'Little Giant', which remained in the $1.0-1.5$ range. It is notable that two southern highbush cultivars empirically recognized as being more winter hardy ('Magnolia' and 'Ozarkblue') had bud development by week 7 less than or equal to 'Bluecrop'.

Duke was unusual in being the earliest deacclimator, especially since it also has a reputation of being late to flower. The $100 \%$ $V$. ashei cultivar Tifblue was still one of the earlier deacclimators under field conditions, whereas 'Pearl River' (30\% V. ashei) and 'Magnolia' (12\% V. darrowi, 8\% V. ashei) were relatively later deacclimators. While it is possible that the $V$. ashei species can contribute genes determining early deacclimation, it also seems likely that not all genotypes with $V$. ashei in their backgrounds will have inherited those genes. The fact that there are differences in deacclimation timing and rate even among the predominantly $V$. corymbosum cultivars suggests that neither species is fixed for genes determining deacclimation response.

In our previous deacclimation study, deacclimation response did not appear to be strictly related to mid-winter bud hardiness or chilling requirement (Arora et al., 2004). In some cases, the more cold hardy/high-chill genotypes deacclimated later than the more cold sensitive/low-chill genotypes, but there were exceptions. This is the case in the present study, as well. Some of the most coldhardy and presumably high-chill genotypes, like 'Little Giant', 'Northcountry', 'Northsky', and V. constablaei, were some of the latest deacclimators, and one of the most cold sensitive/lowchill genotypes 'Tifblue' was among the earlier deacclimators. However, the fairly cold sensitive/low-chill cultivar Pearl River was one of the later deacclimators, the cold sensitive/low-chill cultivar Legacy was intermediate, and the cold hardy/high-chill cultivar Duke was the earliest deacclimator. Work on chinese elm (Ulmus parvifolia Jacq) (Lindstrom and Dirr, 1991), Vitis L. (Wolf and Cook, 1992), and Solanum L. (Vega et al., 2000) has also found a lack of correlation between timing and/or rate of deacclimation and mid-winter cold hardiness. It is important to note that in our field deacclimation study, the low-chill genotypes would have been exposed to a greater number of chill-hours in excess of their chilling requirements by week 1 than those with higher chilling requirements. However, this differential exposure to number of chill-hours beyond their respective chilling requirements did not appear to have a consistent influence on the timing or rate of deacclimation either.
A highly significant positive correlation was found between the stage of bud opening scores and $\mathrm{BCH}$, averaged over the 2 years $(r=0.84, P<0.0001)$. This is consistent with our earlier results from the deacclimation study using controlled constant, warm temperatures (Arora et al., 2004), and with results from Hancock et al. (1987), where flower bud injury was assessed in 18 cultivars of highbush blueberry ( $V$. corymbosum) after two spring frosts and found to be positively correlated with stage of bud development.

\section{Conclusions}

Results from the present field deacclimation study and our previous controlled deacclimation study (Arora et al., 2004) demonstrate that blueberry genotypes exhibit variability in deacclimation response that may be independent from their midwinter bud hardiness levels and their chilling requirements. More variability among genotypes was observed in the field study than the controlled deacclimation study because of the larger number of genotypes and the inclusion of the late deacclimating $V$. constablaei and half-high genotypes. In addition, under fluctuating temperature conditions in this field study, there is the possibility that the genotypes at times underwent some degree of reacclimation, which may have varied among genotypes. Timing and rate of deacclimation in the early spring or during transient warm spells of winter are key factors determining winter survival of reproductive apices of woody plants (Pellet, 1998). Deacclimation response should, therefore, be considered in breeding programs aimed at improving winter/early spring survival, in addition to mid-winter bud hardiness. Our finding that there is a strong positive correlation between extent of bud opening and deacclimation suggests that bud opening scores could be used as a simple indicator of level of $\mathrm{BCH}$ during a deacclimation regime, possibly permitting an easy way to identify the latest deacclimators. However, for more precise timing of deacclimation, $\mathrm{BCH}$ would have to be determined over a time-course of deacclimation. 'Duke', for example, could not be identified as being an earlier deacclimator 
than 'Northcountry' or 'Northsky' from bud opening scores alone (Table 5).

\section{Literature Cited}

Arora, R., L.J. Rowland, E.L. Ogden, A.L. Dhanaraj, C.O. Marian, M.K. Ehlenfeldt, and B. Vinyard. 2004. Dehardening kinetics, bud development, and dehydrin metabolism in blueberry cultivars during deacclimation at constant, warm temperatures. J. Amer. Soc. Hort. Sci. 129:667-674.

Arora, R., L.J. Rowland, and G.R. Panta. 1997. Chill responsive dehydrins in blueberry: are they associated with cold hardiness or dormancy transitions? Physiol. Plant. 101:8-16.

Arora, R., L.J. Rowland, J.S. Lehman, C.C. Lim, G.R. Panta, and N. Vorsa. 2000 Genetic analysis of freezing tolerance in blueberry (Vaccinium section Cyanococcus). Theor. Appl. Genet. 100:690-696.

Ballington, J.R. 2001. Collection, utilization, and preservation of genetic resources in Vaccinium. HortScience 36:213-220.

Clark, J.R., J.N. Moore, and A.D. Draper. 1996. 'Ozarkblue' southern highbush blueberry. HortScience 31:1043-1045.

Ehlenfeldt, M.K. 1994. The genetic composition and tetrasomic inbreeding coefficients of highbush blueberry cultivars. HortScience 29:1342-1345.

Ehlenfeldt, M.K. and L.J. Rowland. 2005. Cold-hardiness of V. ashei and $V$. constablaei germplasm, and the potential for northern-adapted rabbiteye cultivars. Acta Hort. (in press).

Flinn, C.L. and E.N. Ashworth. 1994. Blueberry flower-bud hardiness is not estimated by differential thermal analysis. J. Amer. Soc. Hort. Sci. 119:295-298.

Hancock, J.F., J.W. Nelson, H.C. Bittenbender, P.W. Callow, J.S. Cameron, S.L. Krebs, M.P. Pritts, and C.M. Schumann. 1987. Variation among highbush blueberry cultivars in susceptibility to spring frost. J. Amer. Soc. Hort. Sci. 112:702-706.

Hancock, J.F. and J.H. Siefker. 1982. Levels of inbreeding in highbush blueberry cultivars. HortScience 17:363-366.

Hanson, E.J. and J.F. Hancock. 1990. Highbush blueberry cultivars and production trends. Fruit Var. J. 44:77-81.

Lindstrom, O.M. and M.A. Dirr. 1991. Cold hardiness of six cultivars of chinese elm. HortScience 26:290-292.

Manly, B.F.J. 1997. Randomization, bootstrap and Monte Carlo methods in biology. 2nd ed. Chapman \& Hall, London.

Milliken, G.A. and D.E. Johnson. 2002. Analysis of messy data-Volume III: Analysis of covariance. Chapman \& Hall/CRC, London.

Moore, J.N. 1993. The blueberry industry of North America. Acta Hort. $346: 15-26$.
Moore, J.N. 1994. The blueberry industry of North America. HortTechnology 4:96-102.

Muthalif, M.M. and L.J. Rowland. 1994. Identification of dehydrin-like proteins responsive to chilling in floral buds of blueberry (Vaccinium, section Cyanococcus). Plant Physiol. 104:1439-1447.

Pellett, H. 1998. Breeding of cold hardy woody landscape plants, p. 317-323. In: P.H. Li and T.H.H. Chen (eds.). Plant cold hardiness: Molecular biology, biochemistry, and physiology. Plenum Press, New York.

SAS Institute. 1999. SAS/STAT user's guide. release 8.0. SAS Inst., Cary, N.C.

Sherman, W.B. and R.H. Sharpe. 1978. 'Beckyblue' blueberry. HortScience 13:61.

Spiers, J.M. 1978. Effect of stage of bud development on cold injury in rabbiteye blueberry. J. Amer. Soc. Hort. Sci. 103:452-455.

Trinka, D.L. 1996. Production trends in the cultivated blueberry industry of North America. Acta Hort. 446:33-36.

Vega, S.E., J.P. Palta, and J.B. Bamberg. 2000. Variability in the rate of cold acclimation and deacclimation among tuber-bearing Solanum (potato) species. J. Amer. Soc. Hort. Sci. 205:205-211.

Wolf, T.K. and M.K. Cook. 1992. Seasonal deacclimation patterns of three grape cultivars at constant, warm temperature. Amer. J. Enol. Viticult. 43:171-179. 